\title{
Radosław Pastusiak
}

Uniwersytet Łódzki

e-mail: radoslaw.pastusiak@uni.lodz.p1

\section{DYSKONTO WARTOŚCI PRZEDSIĘBIORSTWA Z TYTUŁU NADMIERNEGO OPTYMIZMU. PODEJŚCIE MODELOWE}

\section{DISCOUNT OF THE COMPANY'S VALUE DUE TO EXCESSIVE OPTIMISM. MODEL APPROACH}

DOI: $10.15611 /$ pn.2018.533.18

JEL Classification: G02, G17

Streszczenie: Celem artykułu jest wykazanie wpływu zjawiska nadmiernego optymizmu na wartość przedsiębiorstwa. W badaniach zastosowano prosty model optymalizacyjny wykorzystujący dyskonto z tytułu nadmiernego optymizmu w wycenie przedsiębiorstwa. W strukturze przygotowywanych rekomendacji jest więcej rekomendacji pozytywnych niż negatywnych i neutralnych. Statystycznie byłoby to zasadne przy stałym rynku wzrostowym - a przecież na giełdzie jest hossa, bessa, oraz są na niej okresy trendu horyzontalnego. Dlaczego w takim razie w zmieniającej się koniunkturze zawsze przeważają rekomendacje pozytywne? Na podstawie badań w artykule wskazano, że dominuje właśnie taki typ rekomendacji. Następnie porównano cenę notowań w dniu wydania rekomendacji pozytywnych do ceny, jaką spółka osiągnęła po roku notowań. Uzyskane wyniki wskazują, że mimo pozytywnych rekomendacji domów brokerskich znaczna część rekomendacji w spółkach podaje cenę za wysoką w stosunku do ceny realnie uzyskiwanej przez przedsiębiorstwo na GPW. Analiza wykazała również nadmierny optymizm wśród analityków.

Słowa kluczowe: nadmierny optymizm, wycena przedsiębiorstwa, heurystyki, dyskonto.

Summary: The aim of the article is to show the impact of the phenomenon of excessive optimism on the value of the company. The research used a simple optimization model that uses the discount for excessive optimism in the valuation of the company. There are more positive than negative and neutral recommendations in the structure of prepared recommendations. Statistically, it would be reasonable for a stable growth market. And yet the stock market has a bull market, a bear market, and a period of horizontal trend. Why then, in the changing economic climate, positive recommendations always prevail. Research has shown that positive recommendations dominate. Then, the quotation price was compared on the day the positive recommendations were issued for the price that the company achieved after the quotation year. The obtained results indicate that despite the positive recommendations of brokerage houses, a significant part of the recommendations in companies gives a high price in relation to the actual earned by the company on the WSE. This analysis also showed the existence of excessive optimism among analysts.

Keywords: excessive optimism, the valuation of the company, heuristics. 


\section{Wstęp}

Nadmierny optymizm jest zjawiskiem występującym podczas podejmowania decyzji przez człowieka. Jest on wynikiem zakotwiczenia, jakiemu ulega człowiek w swoich przekonaniach, rozumieniu rzeczywistości czy posiadanej wiedzy. Na rynku kapitałowym również mamy do czynienia ze zjawiskiem nadmiernego optymizmu. Jednym z obszarów, na jaki wpływa nadmierny optymizm, jest wycena przedsiębiorstwa. Celem artykułu jest pokazanie znaczenia dyskonta z tytułu nadmiernego optymizmu dla wartości firm na rynku kapitałowym w Polsce. Jako obszar analizy możliwego występowania nadmiernego optymizmu wykorzystano wyceny przedsiębiorstw wykonywane przez analityków finansowych w rekomendacjach giełdowych, które są wydawane przez domy brokerskie. Szczególnym elementem zainteresowania autora jest prognozowany $\mathrm{w}$ nich kierunek zmiany ceny oraz docelowe wartości akcji podawane w rekomendacjach.

Dotychczasowe badania w zakresie nadmiernego optymizmu koncentrują się na opisie zjawiska oraz na próbie wyjaśnienia jego przyczyn. Dyskonto stosowane $\mathrm{w}$ procesie wyceny firmy ma o wiele większą reprezentację $\mathrm{w}$ literaturze przedmiotu. Najważniejsze pozycje literaturowe z tych dwóch obszarów wraz z wnioskami istotnymi dla tego artykułu zaprezentowano w dalszej części tekstu.

\section{Przegląd literatury przedmiotu}

W literaturze dotyczącej badań nad psychologią człowieka pojęcie optymizmu thumaczone jest jako z reguły niezmienna w czasie i niezależna od bieżącej sytuacji indywidualna cecha osobowości. Osoba optymistyczna wierzy, że w życiu będzie miała styczność z doświadczeniami raczej pozytywnymi niż negatywnymi. W szerszym rozumieniu optymizm jest często kojarzony z nierealistycznym podejściem do życia, w którym to osoba wykazuje bezpodstawne przekonanie o swoim szczęśliwym losie. Rozumiany w ten sposób optymizm, prowadzi do błędnej oceny możliwości wystąpienia określonych zdarzeń [Czerw 2009, s.15]. Poznawszy psychologiczne wytłumaczenie pojęcia optymizmu, można przedstawić założenia koncepcji nadmiernego optymizmu w świetle nauki finansów.

Nadmierny optymizm przejawia się w przekonaniu określonej osoby, że negatywne zdarzenie przytrafi się komuś innemu, a szczęśliwy scenariusz będzie jej udziałem. Inwestor, który wykazuje zbytni optymizm, posiada skłonność do podejmowania decyzji zbyt ryzykownych, gdyż wierzy, że jest mniej podatny na niekorzystne konsekwencje płynące z tejże decyzji. Za przykład może posłużyć zachowanie inwestorów giełdowych, którzy dokonują spekulacyjnego zakupu instrumentów finansowych charakteryzujących się wysoką zmiennością stóp zwrotu [Szyszka 2007, s. 51]. A. Szyszka opisuje nadmierny optymizm, jako „nierealistyczne myślenie życzeniowe". Zwraca on uwagę na wpływ nadmiernego optymizmu na występowanie błędów w interpretacji publicznych informacji. Jeżeli nowe wiadomości ryn- 
kowe są sprzeczne z uprzednimi przywidywaniami uczestników giełdowych, to reakcja całego rynku kapitałowego na nowe informacje jest słabsza. Potwierdzeniem tej reguły jest badanie przeprowadzone przez K. Womacka, w którym to wyliczony stosunek liczby rekomendacji kupna i sprzedaży wyniósł 7:1 [Womack 1996, s. 137-167].

M. Czerwonka oraz B. Gorlewski [2012, s. 100-101] zwracają uwagę na to, że osoba charakteryzująca się nadmiernym optymizmem na rynku kapitałowym jest narażona na przewartościowanie swojej wiedzy i umiejętności, błędną ocenę ryzyka oraz złudną zdolność do przewidywania zdarzeń, a co gorsza - zysków.

Ponadto za najważniejsze tezy w nauce dotyczącej nadmiernego optymizmu na rynku kapitałowym i jego przyczyn uważa się opinie:

- Kahnemana i Tversky'ego [1971; 1974] - problem racjonalności decydenta;

- Nofsingera [2011, s. 196-200], Olsena [1997, s. 62-66] - w zakresie optymizmu inwestorów i nadmiernej kontroli;

- Zaleśkiewicza [2015] i Zielonki [2014] - w zakresie błędów i zniekształceń prognozowania;

- Nęckiego, Orzechowskiego i Szymury [2008] - w zakresie heurystyk zakotwiczenia i dostosowania, dostępności i reprezentatywności;

- Montiera [2007] - analizę przyczyn błędów w prognozach;

- Wąsowskiej [2013] - analizę błędów i ich przyczyn popełnianych przez audytorów.

- Eamesa [2002] - analizę pozytywnych i negatywnych błędów prognozy.

- Zielonki [2014] - analizę błędów w kontekście efektu ponadprzeciętności, efektu kalibracji, iluzji kontroli i nieuzasadnionego optymizmu.

- Tyszki i Zielonki [2002], Plousa [1993], Törngrena i Montgomeriego [2004].

Wycena przedsiębiorstwa jest obszarem podejmowanym przez wielu badaczy; najważniejsze tezy w tej dziedzinie opracowali Damodaran [2006] i Zarzecki [1999; 2011]. Autorzy jako jedną z procedur dostosowawczych opisują dyskonto [Damodaran 2005; Kołodziejczyk i in. 2013]. Dyskonto to pojęcie zmiany wartości związane z wpływem określonego czynnika. Może być to na przykład czas. W przypadku wycen przedsiębiorstwa dyskonta mają za zadanie skorygowanie wartości firmy wynikłej z prognozy finansów przedsiębiorstwa o negatywny wpływ jakiegoś czynnika. Jedną z podstawowych publikacji w zakresie dyskont jest praca Pratt Shannon [2009], w której opisano większość stosowanych dyskont wraz z ich założeniami. Jednym z czynników, jakie można uwzględnić przy wycenie przedsiębiorstwa, jest dyskonto $\mathrm{z}$ tytułu nadmiernego optymizmu.

\section{Metodyka}

Na potrzeby osiągnięcia celu badania wykorzystano bazę danych spółek notowanych na GPW w Warszawie, dla których są publikowane rekomendacje maklerskie z wyceną przedsiębiorstwa. Okres wyboru tychże rekomendacji to lata 2000-2013. 
Istotnym założeniem uwzględnionym przy wyborze spółek było odrzucenie wszystkich podmiotów, które w analizowanym okresie ogłosiły, iż będą uczestniczyć w takich działaniach, jak fuzja, przejęcie czy rebranding. Te zdarzenia są na tyle istotne, zmieniając charakter przedsiębiorstwa i jego wartość, że jeśli informacja o tym fakcie nie była znana w momencie dokonywania wyceny, to oszacowanie przyszłych cash flow firmy oraz określenie jej rynkowej wartości w relatywnie precyzyjny sposób było niemożliwe. W analizach nie uwzględniono również rekomendacji dla sektora bankowego i finansowego.

Dla każdej ze spółek przeanalizowano zestaw danych według szablonu jak w tabeli 1, dotyczących przykładowej spółki, dla rekomendacji pozytywnych (kupuj, akumuluj) i negatywnych (sprzedaj, redukuj). Przy tak skonstruowanej bazie danych w badaniu podano analizie ponad 7500 rekomendacji o charakterze pozytywnym oraz ponad 1500 rekomendacji o charakterze negatywnym. Raporty neutralne nie zostały uwzględnione w badaniu ze względu na swoją niekonkluzywność w predykcji zmiany ceny ocenianego waloru.

Dane z tabeli 1 oznaczają, że wycena każdej spółki jest opisywana przez zbiór danych, z których najważniejsze to cena w momencie publikacji rekomendacji i cena docelowa (czyli cena w rekomendacji do jakiej należy kupować lub sprzedawać). Analizie poddawana jest różnica w cenach, wyrażona procentowo, po roku od publikacji rekomendacji. Przykładowy rozkład stóp zwrotu dla rekomendacji pozytywnych widzimy w tabeli 1 .

Tabela 1. Matryca danych dotycząca cen akcji przykładowej spółki dla rekomendacji pozytywnych

\begin{tabular}{|l|c|c|c|c|}
\hline $\begin{array}{c}\text { Data wystawienia } \\
\text { rekomendacji }\end{array}$ & $\begin{array}{c}\text { Cena docelowa } \\
\text { w rekomendacji }\end{array}$ & $\begin{array}{c}\text { Cena } t-\text { cena } \\
\text { w momencie } \\
\text { publikacji } \\
\text { rekomendacji }\end{array}$ & $\begin{array}{c}\text { Cena } t+250- \\
\text { cena po roku }\end{array}$ & $\begin{array}{c}R t+250-\text { stopa } \\
\text { zwrotu po roku }\end{array}$ \\
\hline 21.03 .2007 & 21 & 15,75 & 9,48 & $-50,77 \%$ \\
\hline 08.01 .2007 & 17,1 & 15,89 & 10,15 & $-44,82 \%$ \\
\hline 24.01 .2011 & 12 & 8,65 & 5,68 & $-42,06 \%$ \\
\hline 17.09 .2010 & 10,35 & 9,18 & 6,5 & $-34,52 \%$ \\
\hline 02.03 .2011 & 11,53 & 8,45 & 6,4 & $-27,79 \%$ \\
\hline 02.03 .2011 & 12,27 & 8,45 & 6,4 & $-27,79 \%$ \\
\hline 16.05 .2011 & 11,3 & 8,3 & 6,79 & $-20,08 \%$ \\
\hline 14.11 .2006 & 17 & 14 & 13,35 & $-4,75 \%$ \\
\hline 08.06 .2010 & 8,39 & 7,8 & 8,1 & $3,77 \%$ \\
\hline 05.03 .2013 & 10,63 & 8,42 & 9,04 & $7,10 \%$ \\
\hline 18.04 .2006 & 18,9 & 16,15 & 19,6 & $19,36 \%$ \\
\hline 12.12 .2012 & 9,31 & 7,99 & 9,82 & $20,62 \%$ \\
\hline 14.09 .2009 & 6,34 & 5,01 & 9,4 & $62,93 \%$ \\
\hline 28.05 .2009 & 3,4 & 2,77 & 7,15 & $94,83 \%$ \\
\hline
\end{tabular}

Źródło: opracowanie własne. 
Komentując wartości w pierwszym rzędzie, należy stwierdzić, że cena spółki w momencie rekomendacji wynosiła $15,75 \mathrm{zl}$, a cena docelowa - 21 zł. To znaczy, że spółka została wyceniona z potencjałem wzrostu na 33,3\%. W rzeczywistości po roku wartość akcji spółki obniżyła się do 9,48 zł. Zakładając, że wycena spółki została zrobiona rzetelnie i zgodnie z zasadami, analityk przeszacował wartość firmy w wycenie, wykazując się tym samym nadmiernym optymizmem.

Po wyselekcjonowaniu podmiotów w badaniu przeprowadzono analizę wycen według struktury rekomendacji giełdowych dla poszczególnych przedsiębiorstw. Analiza ta miała na celu wstępne ustalenia dotyczące charakteru wystawianych rekomendacji i miała dostarczyć informacji o tym, czy istnieje przewaga którejś grupy raportów analitycznych nad pozostałymi. Zgodnie ze stawianą przez badacza hipotezą o nadmiernym optymizmie analityków giełdowych należy spodziewać się, iż raporty o wydźwięku pozytywnym stanowią grupę przeważającą w ogólnej puli analizowanych rekomendacji. Należy tu podkreślić, że analizowany okres 2000-2013 jest na tyle rozciągnięty, że obejmuje okresy zarówno wzrostów, spadków, jak i stagnacji. Zmienność warszawskiej giełdy spowodowała, że nominalnie indeks WIG wzrósł z około 20 tys. punktów do 51 tys. punktów, ale w międzyczasie występowały okresy dynamicznej hossy i głębokiego załamania. Biorąc pod uwagę zróżnicowanie koniunkturalne objęte badaniem, należałoby się spodziewać, że w różnych okresach, publikowane raporty powinny opierać się na zróżnicowanych założeniach i analizach skutkujących odmiennymi rekomendacjami nie tylko w zakresie docelowych cen, ale również w zakresie przewidywanego kierunku zmiany w analizowanym horyzoncie. Warto podkreślić, że wśród badanych rekomendacji przeważają takie, które prognozują wartość spółki w horyzoncie od roku do dwóch (nie jest to równoznaczne z liczbą lat w prognozach DCF wykonywanych przez analityków). Tabela 2 zawiera zestawienie miar statystycznych dla wycen wszystkich spółek w okresie objętym analizą.

Tabela 2. Zestawienie miar statystycznych dla wszystkich wycen (w \%)

\begin{tabular}{|l|c|c|c|c|c|}
\hline \multicolumn{1}{|c|}{ Zmienna } & Średnia & Mediana & $\begin{array}{c}\text { Odchylenie } \\
\text { standardowe }\end{array}$ & Minimum & Maksimum \\
\hline $\begin{array}{l}R_{t+250} \text { wynikająca z rekomendacji } \\
\text { negatywnych }\end{array}$ & 5,32 & 9,06 & 65,49 & $-365,25$ & 729,16 \\
\hline $\begin{array}{l}R_{t+250} \text { wynikająca z rekomendacji } \\
\text { pozytywnych }\end{array}$ & $-19,35$ & $-12,76$ & 64,78 & $-554,50$ & 679,49 \\
\hline
\end{tabular}

Źródło: opracowanie własne.

Dane zawarte w tabeli 2 wskazują na to, że średnia stopa zwrotu $R t$ z wyceny zawartych $\mathrm{w}$ rekomendacjach pozytywnych wyniosła $-19,35 \%$, a to oznacza, że średnio wycena $\mathrm{w}$ rekomendacji pozytywnej została przeszacowana w stosunku do realnej o 19,35\%. Natomiast średnia cena docelowa w rekomendacji negatywnej została niedoszacowana o 5,32\% w stosunku do ceny realnie osiągniętej. 
Po wykonaniu wstępnej analizy strukturalnej przystąpiono do określenia poprawności predykcji ceny docelowej poszczególnych akcji. Posłużono się prostym modelowaniem liniowym w postaci klasycznej metody najmniejszych kwadratów. Skonstruowano model dla wszystkich spółek, całego portfela, w postaci:

$$
C 250_{i}=\beta_{i} \times C r_{i}+e_{i},
$$

gdzie: $C 250$ - cena akcji spółki 250 sesji po publikacji raportu,

$\mathrm{Cr}$ - cena docelowa zaproponowana w rekomendacji.

W modelu celowo pominięto wyraz wolny, aby cały ciężar przewidywania ceny docelowej był skumulowany $\mathrm{w}$ estymowanym współczynniku $\beta$. Zdaniem autora taki zabieg pozwala na lepsze porównanie współczynników między poszczególnymi modelami wykonanymi dla różnych spółek i przez to dla różnych zestawów zmiennych. W artykule świadomie zastosowano wskazaną postać modelu, mając na względzie, że estymator oszacowany zgodnie z jego kształtem może nie mieć cech BLUE. Artykuł prezentuje wstępną analizę badanego zjawiska i prezentowany model stanowczo nie jest postacią docelową. Jest to jedynie próba pokazania charakteru (typu) związku, który jest analizowany w toku przeprowadzonych badań.

Test średnich, który został zaprezentowany w dalszej części niniejszego tekstu, nie ma na celu zastąpienia testu istotności estymatora $\beta$. Jest to uzupełniający element analizy.

Otrzymane wyniki przeanalizowano i przetestowano w zakresie istotności otrzymanej średniej. Wykorzystano do tego celu prosty test istotności o postaci:

$$
t=\frac{\bar{X}-\mu_{0}}{S} \sqrt{n-1},
$$

gdzie: $X$ - średnia z próby,

$\mu$ - testowana wartość średniej,

$S$ - odchylenie standardowe,

$n$ - liczebność próby.

Na podstawie otrzymanych wyników sformułowano wnioski dotyczące występowania nadmiernego optymizmu wśród analityków tworzących rekomendacje giełdowe oraz jego wpływu na wartość wycenianego przedsiębiorstwa. Postawiono hipotezę, iż analitycy wykazują tendencję do przeszacowywania cen $\mathrm{w}$ swoich prognozach. Oba te aspekty są silną przesłanką do stwierdzenia występowania nadmiernego optymizmu wśród analityków giełdowych, a także do skonstruowania wskaźnika dyskonta za nadmierny optymizm dla całego portfela analizowanych spółek. Wyniki analiz przedstawiono w tabelach 3 i 4 . Należy jednak zaznaczyć, iż zaproponowana na tym etapie formuła jest daleka od docelowej, znacznie precyzyjniejszej, która będzie uwzględniała cechy analityka oraz samej rekomendacji, przy ustalaniu poziomu dyskonta. Zaprezentowane poniżej formuły mają na celu wskazanie głównego kierunku badań i podejścia do omawianego zjawiska. 
Tabela 3. Zestawienie miar statystycznych dla wszystkich wycen - rekomendacje pozytywne

\begin{tabular}{|c|c|c|c|c|c|}
\hline \multirow{2}{*}{ Potencjał } & Współczynnik & Błąd stand. & $t$-Studenta & Wartość $p$ & \\
\cline { 2 - 6 } & 0,00499399 & 0,000444987 & 11,2228 & $<0,00001$ & $* * *$ \\
\hline
\end{tabular}

Podstawowe statystyki dla ważonych danych:

\begin{tabular}{|l|c|l|c|}
\hline Suma kwadratów reszt & 542916,6 & Błąd standardowy reszt & 8,811195 \\
\hline Wsp. determ. $R$-kwadrat & 0,008098 & Skorygowany $R$-kwadrat & 0,008098 \\
\hline$F(1,6993)$ & 57,08913 & Wartość $p$ dla testu F & $4,70 \mathrm{e}-14$ \\
\hline Logarytm wiarygodności & $-25142,66$ & Kryt. inform. Akaikego & 50287,32 \\
\hline Kryt. Bayesa-Schwarza & 50294,18 & Kryt. Hannana-Quinna & 50289,68 \\
\hline
\end{tabular}

Źródło: opracowanie własne.

Tabela 4. Zestawienie miar statystycznych dla wszystkich wycen - rekomendacje negatywne

\begin{tabular}{|c|c|c|c|c|c|}
\hline & Współczynnik & Błąd stand. & $t$-Studenta & Wartość $p$ & \\
\hline Potencjał & 0,207813 & 0,012881 & 16,1333 & $<0,00001$ & $* * *$ \\
\hline
\end{tabular}

Podstawowe statystyki dla ważonych danych:

\begin{tabular}{|l|c|l|c|}
\hline Suma kwadratów reszt & 1243618 & Błąd standardowy reszt & 28,59426 \\
\hline Wsp. determ. $R$-kwadrat & $-0,266644$ & Skorygowany $R$-kwadrat & $-0,266644$ \\
\hline $\mathrm{F}(1,1521)$ & $-320,1887$ & Wartość $p$ dla testu F & NA \\
\hline Logarytm wiarygodności & $-7262,704$ & Kryt. inform. Akaikego & 14527,41 \\
\hline Kryt. Bayesa-Schwarza & 14532,74 & Kryt. Hannana-Quinna & 14529,39 \\
\hline
\end{tabular}

Źródło: opracowanie własne.

Wyniki z tych tabel, szczególnie wartości współczynnika dla zmiennej potencjału, wskazują na konieczność redukcji wartości ceny docelowej w prognozach wyceny wartości firm dla rekomendacji pozytywnych i negatywnych.

\section{Wyniki badań}

W pierwszej kolejności analizie poddano strukturę rekomendacji poszczególnych spółek. Zaznaczmy tutaj, że nomenklatura używana w różnych domach maklerskich, dotycząca ostatecznej rekomendacji, jest nieco inna w poszczególnych instytucjach, więc autor musiał dokonać ujednolicenia poszczególnych typów raportów analitycznych umożliwiającego dokonanie analizy porównawczej między domami maklerskimi. Ostatecznie rekomendacje sprowadzono do 5 podstawowych grup: kupuj, akumuluj, neutralnie redukuj, sprzedaj.

Raporty o wydźwięku pozytywnym, czyli łącznie grupy „kupuj” i „akumuluj”, przeważają nad raportami negatywnymi. Średnio udział raportów pozytywnych w łącznej puli rekomendacji przekracza $83 \%$, czyli ponad 8 na 10 wystawianych 
prognoz cenowych wskazuje na przyszłe wzrosty, niezależnie od koniunktury, spółki i domu maklerskiego.

Duża liczba pozytywnych rekomendacji pozytywnych jest z pewnością przesłanką do stwierdzenia, że analitycy bardzo chętnie wysnuwają pozytywne prognozy, lecz zasadniczą kwestią w tym kontekście jest to, czy ich optymizm jest poparty realnymi przesłankami i czy potwierdza się on w przyszłości w faktycznych cenach walorów giełdowych. W tabeli 5 zaprezentowano zestawienie różnic między cenami rynkowymi a prognozami analityków.

Tabela 5. Odchylenia cenowe między rekomendacjami a realnymi cenami w perspektywie rocznej (w \%)

\begin{tabular}{|c|c|c|c|c|c|}
\hline Zmienna & Średnia & Mediana & $\begin{array}{c}\text { Odchylenie } \\
\text { standardowe }\end{array}$ & Minimum & Maksimum \\
\hline Różnica z negatywnych rekomendacji & 5,32 & 9,06 & 65,49 & $-365,25$ & 729,16 \\
\hline Różnica z pozytywnych rekomendacji & $-19,35$ & $-12,76$ & 64,78 & $-554,50$ & 679,49 \\
\hline
\end{tabular}

Źródło: opracowanie własne.

Z zaprezentowanych wcześniej modeli oraz z tabeli 5 wynika, że rekomendacje wskazywały średnio na zmiany cen wyższe niż faktycznie miały miejsce. Możemy więc wnioskować, że strukturalny wniosek dotyczący zbyt optymistycznych osądów znajduje również potwierdzenie w typowanych przez analityków cenach. Zwróćmy uwagę, że różnice obliczone dla badanej zbiorowości wskazują na przeszacowania w raportach pozytywnych i negatywnych na poziomie nawet kilkuset procent. Są to wartości znaczące i skłaniające do refleksji nad proponowanym zagadnieniem nadmiernego poziomu optymizmu analityków.

$\mathrm{W}$ formie prostego modelu liniowego zaprezentowano uzależnienie realnej zmiany ceny rekomendowanej spółki w zależności od przewidywanego przez analityka potencjału jej wzrostu zawartego w rekomendacji. Na podstawie modelu o postaci, która została zaprezentowana w tabeli 3, możemy orzec, że w ujęciu bardzo ogólnym przewidywania maklerów (bez zastosowania szczegółowych wyróżników dla każdej rekomendacji oraz analityka) są bardzo mocno przeszacowane w rocznej perspektywie. Horyzont ten został również uwzględniony jako uśrednienie perspektyw deklarowanych w poszczególnych rekomendacjach, które waha się od 9 do 15 miesięcy.

Współczynnik korygujący potencjał wzrostu ustalony zgodnie z metodą MNK nakazuje średnie przeszacowanie przewyższające $99 \%$. Wartość ta wynika między innymi z faktu, iż w badanej próbie znajduje się spora liczba obserwacji wskazujących na kilkuset procentowe pomyłki co do wielkości potencjału wzrost udanej spółki. W przypadku rekomendacji negatywnych zaproponowany model wskazuje na konieczność mniejszej, aczkolwiek nadal bardzo znaczącej redukcji, bliskiej 80\% prognozowanego potencjału wzrostu. W tabeli 5 wskazano, że średnia różnica między prognozowanym procentem wzrostu ceny i faktycznym procentem zmiany wy- 
nosi dla rekomendacji negatywnych 5,32, zaś dla pozytywnych $-19,35 \%$. Mediana tych różnic dla rekomendacji negatywnych wynosi natomiast 9,06\%, a dla rekomendacji pozytywnych $-12,76 \%$. Widać więc, że średni błąd nie jest tak wysoki, jak wskazywałby współczynnik w modelu zawartych w tabeli 3. Jednak łącząc te wszystkie informacje, należy zauważyć, że błędy popełniane przez analityków w wykonywanych wycenach spółek są znaczne, a rozpiętość wycen jest duża. To natomiast implikuje konieczność ustalenia szerokiej grupy wyróżników charakteryzujących poszczególne rekomendacje, które pozwolą na precyzyjne ujęcie współczynnika przeszacowania dla poszczególnych raportów. Oczywiście celem wykonywanych analiz jest ustalenie procedury dającej możliwość zastosowania współczynnika korygującego w momencie wydania rekomendacji, a nie po roku od jej publikacji.

\section{Zakończenie}

W strukturze badanych rekomendacji jest znacznie więcej rekomendacji pozytywnych niż negatywnych, co, zważając na fakt ujęcia w okresie analiz pełnych cykli koniunkturalnych zarówno gospodarczych, jak i giełdowych, stanowi przesłankę do orzeczenia, iż problem nadmiernego optymizmu analityków jest realny w warunkach funkcjonowania polskiej giełdy. Statystycznie tak optymistyczne prognozy byłyby zasadne przy stałym rynku wzrostowym, co oczywiście nie miało i nie może mieć miejsca na przestrzeni tak wielu lat (13). Dlaczego w takim razie w zmieniającej się koniunkturze zawsze przeważają rekomendacje pozytywne? Przeprowadzone badanie wskazało, że na rynku dominują rekomendacje pozytywne, lecz zakres błędów prognostycznych objawiających się w postaci znacznych przeszacowań wzrostu wartości spółek w dużej mierze osłabia ich wiarygodność.

W badaniu zaprezentowano wstępne analizy dotyczące sposobu weryfikacji wielkości przeszacowania w poszczególnych rekomendacjach, dążące do ustalenia możliwej procedury korygowania proponowanych w rekomendacjach cen docelowych, w momencie opublikowania danego opracowania oraz z założeniem realizacji inwestycji na ich podstawie w horyzoncie rocznym. Autor wskazuje na znaczny problem wręcz notorycznego przeszacowania wartości prognostycznych w rekomendacjach maklerskich, który wywołuje potencjalnie nieprawidłowe decyzje inwestycyjne wśród odbiorców tych raportów. Zaproponowana metodyka badawcza ma charakter ogólny i wskazujący kierunek prowadzonych badań. Będzie ona uszczegóławiana w przyszłości poprzez zaproponowanie odpowiedniego zestawu zmiennych charakterystycznych zarówno dla samej rekomendacji, jak i osoby wykonującej tego typu opracowanie, dzięki czemu proponowana procedura korekty ceny docelowej będzie mogła być stosowana w sposób bardziej precyzyjny i w odniesieniu do warunków wydania poszczególnych rekomendacji. Autor ma świadomość, iż jeden współczynnik korygujący, który byłby zasady dla całej grupy rekomendacji wystawianych na polskim rynku, nawet z podziałem tych raportów na pozytywne i nega- 
tywne, nie jest możliwy do ustalenia w zasadny i użyteczny sposób. Dlatego też przyszłe badania wykonywane w zakresie próby ujęcia liczbowego, heurystyki nadmiernego optymizmu, będą nakierowane na zaproponowanie konkretnego zestawu zmiennych opisujących poszczególne rekomendacje, a na podstawie których będzie można w statystycznie istotny sposób dokonać korekty poszczególnych wycen.

\section{Literatura}

Czerw A., 2009, Optymizm. Perspektywa psychologiczna, Gdańskie Wydawnictwo Psychologiczne, Sopot.

Czerwonka M., Gorlewski B., 2012, Finanse behawioralne. Zachowania inwestorów i rynku, Szkoła Główna Handlowa w Warszawie, Warszawa.

Damodaran A., 2005, Marketability and Value: Measuring the Illiquidity Discount, July, http://pages. stern.nyu.edu/ adamodar/pdfiles/papers/liquidity.pdf (25.05.2018).

Damodaran A., 2006, Damodaran on Valuation, Wiley Finance, New Jersey.

Das S., Levine C.B., Sivaramakrishnan K., 1998, Earnings Predictability and bias in analysts' earnings forecasts, Accounting Review, vol. 73, no. 2.

Eames M., Glover S.M., Kennedy J., 2002, The association between trading recommendations and broker-analysts' earnings forecasts, Journal of Accounting Research, 40, s. 85-104.

Gajdka J., 2013, Behawioralne finanse przedsiębiorstw. Podstawowe podejścia i koncepcje, Wydawnictwo Uniwersytetu Łódzkiego, Łódź.

Kołodziejczyk M., Lasota J., Piechota P., 2013, Dyskonto z tytułu braku płynności w wycenie spółek notowanych na GPW, Zeszyty Naukowe Uniwersytetu Szczecińskiego, nr 761, Finanse, Rynki Finansowe, Ubezpieczenia, nr 60, http://www.fmc.home.pl/upload/news/pdf_news_13651786 93.pdf (18.06.2013).

Lim T., Rationality and analysts'forecast bias, Journal of Finance, vol. 56, no. 1.

Montier, J., 2007, Behavioural Investing: A Practitioners Guide to Applying Behavioural Finance, Wiley, Chichester.

Nęcka E., Orzechowski J., Szymura B., 2008, Psychologia poznawcza, Wydawnictwo Naukowe PWN, Warszawa.

Nofsinger J.R., 2011, Psychologia inwestowania, Helion, Gliwice.

Olsen R., 1997, Investment risk: The experts'perspective, Financial Analysts' Journal, 53, s. $62-66$.

Olsen R., Throughton G.H., 2000, Are risk premium anomalies caused by ambiguity, Financial Analysts Journal, 56, s. 24-31.

Plous S., 1993, The Psychology of Judgment and Decision Making, McGraw-Hill, New York.

Pratt Shannon P., 2009, Business Valuation Discounts and Premiums, John Wiley \& Sons, Hoboken, NJ.

Pompian M.M., 2006, Behavioral finance and Wealth Management: How to Build Optimal Portfolios that Account for Investor Biases, John Wiley \& Sons.

Szyszka A., 2007, Wycena papierów wartościowych na rynku kapitałowym w świetle finansów behawioralnych, Wydawnictwo Akademii Ekonomicznej w Poznaniu, Poznań.

Szyszka A., 2009, Behawioralne aspekty kryzysu finansowego, Bank i Kredyt, 40, 4, s. 5-30.

Törngren G., Montgomery H., 2004, Worse than chance? Performance and confidence among professionals and laypeople in the stock market, Journal of Behavioral Finance, 5, s. 148-153.

Tversky A., Kahneman D., 1971, Belief in the law of small numbers, Psychological Bulletin, 76 (2), s. $105-110$. 
Tversky A., Kahneman D., 1974, Judgment under uncertainty: Heuristics and biases, Since, 185, s. $1124-1131$.

Tyszka T., Zielonka P., 2002, Expert judgments: Financial analysts versus weather forecasters, The Journal of Psychology and Financial Markets, 3 (3), s. 152-160.

Wąsowska A., 2013, Heurystyki i błędy poznawcze jako źródta niepowodzenia audytu zewnętrznego, Problemy Zarządzania, 11, 3, s. 189-202.

Womack K., 1996, Do brokerage analysts' Recommendation have investment value?, Journal of Finance, vol. 51, no. 1.

Zaleśkiewicz T., 2015, Psychologia ekonomiczna, Wydawnictwo Naukowe PWN, Warszawa.

Zarzecki D., 1999, Metody wyceny przedsiębiorstw, Fundacja Rozwoju Rachunkowości w Polsce, Warszawa.

Zarzecki D., 2011, O kluczowych wyzwaniach wyceny przedsiębiorstw, wycenie zobowiazań warunkowych $i$ wycenie aktywów nieoperacyjnych, Prace Naukowe Uniwersytetu Ekonomicznego we Wrocławiu, nr 158.

Zielonka P., 2014, Giełda i psychologia. Behawioralne aspekty inwestowania na rynku papierów wartościowych, $\mathrm{CeDeWu}$, Warszawa.

Zweig J., 2009, How to Ignore the Yes-Man in Your Head, Dow Jones \& Company, 19.11.2009, (8.05.2016). 